\title{
THE ANTI-COMMUNIST MOMENT: COMPETITIVE VICTIMHOOD IN EUROPEAN POLITICS
}

\author{
Máté Zombory
}

Presses Universitaires de France | «Revue d'études comparatives Est-Ouest »

2020/2 N²-3 | pages 21 à 54

ISSN 0338-0599

ISBN 9782130823452

\section{Article disponible en ligne à l'adresse :}

https://www.cairn.info/revue-revue-d-etudes-comparatives-estouest-2020-2-page-21.htm

Distribution électronique Cairn.info pour Presses Universitaires de France.

(C) Presses Universitaires de France. Tous droits réservés pour tous pays.

La reproduction ou représentation de cet article, notamment par photocopie, n'est autorisée que dans les limites des conditions générales d'utilisation du site ou, le cas échéant, des conditions générales de la licence souscrite par votre établissement. Toute autre reproduction ou représentation, en tout ou partie, sous quelque forme et de quelque manière que ce soit, est interdite sauf accord préalable et écrit de l'éditeur, en dehors des cas prévus par la législation en vigueur en France. Il est précisé que son stockage dans une base de données est également interdit. 


\section{THE ANTI-COMMUNIST MOMENT: COMPETITIVE VICTIMHOOD IN EUROPEAN POLITICS}

Máté Zombory,

Senior research fellow, Centre for Social Sciences, Hungarian Academy of Sciences Centre of Excellence;

matezombory@yahoo.com

ABSTRACT - Drawing on Pierre Bourdieu's theory, this article argues that the field of the political debates about Europe's "constitutive historical legacies" was characterised by two positions, both inherently anti-communist: the cosmopolitan Holocaust memory framework of the post-Cold War Western European "integrator position" and the heroic-national memory framework of post-Communist countries "returning to Europe." The interaction of these two positions was influenced by the conditionality of the enlargement process. The debate was thus not de-politicised, as often stated, but consensually anti-communist. The pan-European anti-communist moment hindered politico-ideological framings and changed political struggles into a mimetic competition between self-victimising actors in which claims were moralised and restricted to anti-communism.

KEYWORDS - anti-communism, European politics, memory politics, victimhood, memory of the Holocaust, memory of communism 
This research project was supported by the Collegium de Lyon, where the author was an invited researcher for the academic year 2015-2016, and by the Hungarian National Research, Development, and Innovation Office (NKFIH No. PD 115736). 
In post-1989 European public debates, the memory of the "Gulag" competes with the memory of "Auschwitz" (Droit, 2007) for equal recognition. Power relations in the transnational political field tend to be objectified through the binary logic of these competing memory claims as the debate over the boundaries of the European political community devolves into a controversy over the historical legacies of the past. The question of communism is raised in this setting as a memory issue to be integrated into a common historical narrative of the Holocaust - one capable of providing solidarity within the political community. Furthermore, Nazism and communism themselves are not up for debate in the framework of a possible European memory (Pakier \& Stråth, 2010), but of their asymmetric relationship to one another.

From a sociological perspective, however, it is not those supposedly distinct "memories" that are asymmetrical, but the power field in which actors make their claims in the name of historical suffering. The fundamental question is why and how a political question par excellence, namely the location of the boundaries of the European political community, took the form of a debate over memory; and why political struggles have become restricted to the moralising debates about the public recognition of victims of past political violence. This article contends that the sociological-historical roots of this political transformation lie in the advent of the anti-communist moment in Europe at the end of the Cold War. Simply put, the developing continental anti-communist consensus rendered it quasi impossible to discuss "Europeanness" in ideological and classical political discourses outside of a Cold War framework. With the lack 
of constitutive ideological differences, the debate has unfolded around symbolical questions of memory and identity. The aim of this paper is thus to highlight the constitutive role of anti-communism in European memory politics by tracing its historical and sociological roots. This anticommunist legacy was hardly perceivable in the euphoric "end-of-history" atmosphere and neoliberal hegemony of the 1990s. If we take this anticommunist "political unconscious" into account, public debates about the meanings of Europe appear not as de-politicised discussions in an alleged "ideological vacuum," as is often claimed, but as deeply ideological conflicts. By showing the "memorialisation" of communism, and also the historically contingent interconnection of the discourses of democratisation and Holocaust consciousness, this paper shows the political impact of politics retreating into the realm of memory and morality at large (Bull \& Hansen, 2016). Competitive victimhood in post-Cold War European politics, along with the almost obsessive attention to the affective comparison of Nazism and communism ("Which caused more suffering?"), unfolded against the backdrop of an anti-communist consensus.

There are two main characteristics to the transnational field of positions in which the relationship between Nazism and communism has been contested. The first is the power relation constituted by the claim that the Holocaust was a unique event, in so far as the European debate on its constituent historical legacies showed the same dynamic as earlier historical memory competitions. Analysing the relations generated by public claims of racial and political deportees of the Holocaust, JeanMichel Chaumont (1997) termed this social dynamic the "competition of victims," which was a "perverse effect of the uniqueness claim." However, it is not restricted to the victims of Nazism: Peter Novick also criticised (1999) the competition over "who suffered most" among social groups constructed by different memories of past victimisation. The position taken by the claim of the uniqueness of the Holocaust is challenged by means of other historical experiences of suffering, which then also make a claim to equal recognition. Two opposing sides thus emerge: one side objects to the relativization of the Holocaust, which is even deemed a falsification of history; the other side criticises the monopolisation of suffering and the denial of recognition for the suffering of others. In social struggles over the past, as Tzvetan Todorov has argued (1995, 2000), the claim of uniqueness, even the incomparability and incomprehensibility of 
the Holocaust, sacralises memory and thus impedes historical understanding. As a result, memory discourse becomes increasingly mythological and moralising, reducing historical complexity to the black-and-white lessons of the past. As Charles Maier remarked in relation to the Holocaust Memorial Museum in Washington, DC, "the lesson cannot be just that genocide is evil. This conclusion hardly requires the museum effort" (Maier, 1993, p. 144). He points out that the lessons of the Holocaust justifying the existence of the museum (commemorating the Jewish tragedy in order to prevent it from occurring again) have little to do with history, which of course does not actually repeat itself. Now that the social imperative of the "duty to remember" has acquired international if not universal significance, the question is where the legitimacy of that public claim comes from. Early critics of this memory competition drew attention to how claims of victimisation contribute to the social constitution of groups that presuppose social exclusion. In the strictest sense, however, it is not victims who compete with each other, but rather those making political claims on their behalf - the "spokespersons" in Bourdieu's terms (Bourdieu, 1982). In spite of commemorative gestures of reconciliation, political conflicts over the past tend not to dissipate, precisely because this game of public recognition concerns not the individual, but the status, of the (former) victim. Yet status is connected to prestige, and the equal distribution of symbolic capital is hardly possible in situations of unequal power relations. As such, the public acknowledgement of the status of victim plays the role of qualification in this competition.

Given their rivalry, competing memories are more similar to each other than one would expect (Rousso, 2011, p. 237). In order to explain the "rhetorical and cultural intimacy of seemingly opposed traditions of remembrance" (Rothberg, 2009, p. 7), one has to step beyond the paradigm of exclusive competition and focus on how "competitors" influence each other. From a sociological perspective, the "competition" is a relational space in which positions are taken by actors making memory claims whose interaction is manifested in struggles over competing memories of the past. Instead of conceiving of the space of competition as the neutral space of the market, characterised by the strategic choices of actors on the basis of the demand of "historicisation" and the supply of "reactivated memories" (Mink, Neumayer \& Bonnard, 2007; Mink \& Neumayer, 2013), it is more productive to understand it as a social space in which 
agents struggle over the legitimate vision and divisions of the world (Bourdieu, 1985b). This approach puts emphasis on the unequal power relations constituting the field of positions, in which the "competitors" strive to break the "rules of play" while sharing the social illusion about the stakes of the game (Bourdieu, 1980). By focusing on these rules, the following study aims to explain why post-communist EU member states have striven to incorporate "the experience of Soviet totalitarianism into the foundation of European historical legitimacy" in particular; and how this version of the past has become legitimised in opposition to the "normative reconciliation principle" of older EU member states, which is built around the singularity of the Holocaust (Mink, 2011, p. 262). Indeed, the relative success of the initiative to canonise the representation of communism as a memory of terror and crimes at the European level is largely due to the efficient mobilisation and agenda-setting of post-Communist "memory entrepreneurs" in their "quest for "memory adjustment" (Neumayer, 2015, p. 345). An additional and necessary element of this success was the legitimisation of this initiative, which - despite its highly contested nature (Neumayer, 2019) - made it impossible to refute. Given that both sides were driven by the moral superiority of anti-communism, political differences were articulated symbolically. The changing conditions for legitimately claiming historical events as one's differentia specifica can thus be explained through the binary and antagonistic structure of transnational European memory political space.

The second characteristic of the space of competing European memories is that the positions were constituted by the European enlargement process. What makes the European debate particular in relation to other memory competitions in the past is that it occurred in the midst of a profound geopolitical restructuring triggered by the collapse of the bipolar world order. The spatial problematisation of transnational European politics illuminates how its power asymmetry, perceived by the actors as the unequal recognition of memories, has taken the form of a geographical east-west dichotomy, and thus how the local and the transnational are linked. Actors making memory claims have certainly striven to impose a sacralised idea of "historical experience" that naturally determines the present. From this perspective, after a period of occultation and ignorance, the memory of the Holocaust has finally acquired its rightful recognition; with some delay, the memory of communism, a specific local 
historical experience, has also gradually gained recognition on the European level through a bottom-up process. Normative studies of "Europe's divided memory," arguing for the necessary incorporation of "both events" into the European memory framework (Assmann, 2011), tend to confuse commemorative causality with historical explanation (Snyder, 2013) when dealing with given and geographically specific historical legacies awaiting recognition. According to this explanatory model, history causes regional specificity (there was communism in the East, but not in the West) that automatically demands recognition (the claim that communism existed only in the East must be acknowledged). Thus, a specific interpretation of "Communism" becomes the "particular historical legacy" of Eastern Europe that, as the precondition of integrating the region's nations to Europe, has to be acknowledged as such (Kattago, 2009; Mälksoo, 2014). However, transnational norms clearly influence the way local historical experience is represented and even, to a certain extent, re-lived. In transnational memory studies, the challenge "arises from the difficulty of analyzing and theorizing how something that depends on concrete places and unique historical episodes is shaped by processes that are globalized and to understand how the local then moulds the global in turn" (Sierp \& Wüstenberg, 2015, p. 324). The fact that "memories, especially memories of past atrocities, are spatially grounded" poses analytical problems only if one conceives this groundedness as a given. In ethnography, the problem of cultural rootedness arose three decades ago when scholars began to take into account the apparent interconnectedness of geographically distant social phenomena. The critique of the concept of culture as inherently rooted in geographical or natural space in the age of globalisation (Gupta \& Ferguson, 1992, 2001) oriented scholarly attention to the social processes through which the local and the global are linked. The practices of linking the local and the global are the most visible when the cultural geographical representation of space is questioned in response to social transformation - which is precisely what occurred after the fall of the Iron Curtain. The dissolution of state socialist regimes in Europe entailed a profound geopolitical restructuring in which every agent was forced to reposition themselves. The prevailing instrument for this repositioning was commemoration and history writing, which localised discursive positions in geographical space. The concept of "localisation" was introduced by Maurice Halbwachs (1925), as the process of remembering through which the individual locates the image of the past in the social 
frameworks of memory. In a truly spatial sense, localisation can be applied to space-organising practices that provide a representation of the past: localisation is a spatial practice of remembering (Zombory, 2012). As will be argued here, far from being a local initiative stemming from a specific historical experience, the memory of communism is the result of the localisation of norms of historical consciousness imposed during the EU enlargement process. Consequently, when the denominations of Eastern and Western will be used in the following, those will refer to the main positions of the field assumed by the actors; that is, the East-West division will be treated as a product of repositioning and not a pre-given difference (Tóth, 2019).

The combination of the two particularities of the post-Cold War European political field - the conditionality of EU enlargement and the interconnection of cosmopolitan Holocaust memory (Levy \& Sznaider, 2002) with the discourses on democratisation - had far reaching political consequences. It accelerated the political "bubble effect" (Csigó, 2016), augmenting the gap between political memory claims and the diverse historical experience of those they referenced. It resulted in a "comfortable controversy" in which "each side is so palpably wrong about so many major issues that the other cannot help but feel that it must, in turn, be right" (Snyder, 2013, p. 88). This particular logic was only possible because the various participants were not interested in contesting the commonly shared conditions of legitimate differentiation. Since political difference was acted out in a profoundly, but implicitly, anti-communist context, alongside the Europeanised conditionality of historical authenticity, the debate became more a matter of status competition than historical experiences. The cultural mimesis inherent in European competitive victimhood had profoundly influenced both "sides" and hindered the European project of providing solidarity among citizens with different national and local histories.

In what follows, the anti-communist roots of the relations between the competing memory claims in post-Cold War Europe will be outlined. First, the constitutive role of the Cold War in the post-1945 European history of memory will be discussed: the inherently anti-communist nature of the idea of integration in general and cosmopolitan Holocaust memory in particular, as well as the movement of democratic dissidence. 
Secondly, an analysis of the anti-communist moment of the 1990s will demonstrate how in response to the dissolution of the bi-polar world order both sides strove to reposition themselves: on the one hand, by making the cosmopolitan memory of the Holocaust the central element of the European identity narrative in post-Cold War Western Europe, and by embracing the discourse of a "return to Europe" in post-Cold War Eastern Europe, on the other. Finally, I argue that the institutionalisation of the memory of communism in the late 1990s is a product of the eastwest interaction due to European enlargement.

\section{FROM ANTI-FASCIST TO ANTI-COMMUNIST CONSENSUS}

Since its origins in the 1920s, the anti-fascist movement has maintained an extremely ideological diversity retaining only the common denominator of a rejection of fascism. The anti-fascist consensus during the Second World War was thus an exception and not the rule. The Spanish Civil War, with its failure to achieve such a consensus, prompted opposing revolutionary and counterrevolutionary anti-fascists to join forces against the common enemy at the threshold of a second world war (Seidman, 2018). This wartime consensus, the prerequisite for belligerent alliance, survived only briefly into the early post-war years. Still, as a leftist movement, it provided a common framework for making sense of the moral significance of the atrocities committed during the war which lasted until the 1970s. The most important internal divide fuelling subsequent changes to the anti-fascist movement stemmed from differing attitudes to (anti)communism.

The first schism was clearly visible in the fate of the veteran, resistance, and victim associations that flourished in the immediate aftermath of the Second World War. From 1947 onwards, with the departure of non-communist partisans from the associations, anti-fascism had become a leftist movement with a strong emphasis on the need for revolutionary social change in the fight against the remnants of fascism; in the re-organized anti-communist institutional field, a different interpretation developed that emphasised freedom (of expression, of market exchange, of historical interpretation, etc.) over the perception of communism as a threat. By associating Nazism with communism through the concept of totalitarianism, anti-communists elaborated the idea of concentration camps as the 
supreme symbol of state terror: "In this way, the memory of Nazi persecution became the battle horse of anti-communism" (Lagrou, 1999, p. 269). The idea of Western European integration and the Atlantic alliance, both of which included the Federal Republic of Germany (FRG), developed within this anti-communist social imagery, which posited itself as an essential requirement for the success of the anti-totalitarian struggle: yesterday against Hitler, today against Stalin (Lagrou, 1999).

The universalist moral discourse on the public duty to testify of the Nazi camp victim as "expert witness" of totalitarian oppression came into being through the framework of the early Cold War. David Rousset's 1949 appeal for the creation of an International Commission of Inquiry against the Concentration Camp Regime in the Soviet Union is a symptomatic example: Not only did he call for it after the appeal by the US government at the United Nations to create committees of investigation to prove the existence of concentration camps in the Soviet Union, but from 1951 onward Rousset's group received funding from the US Central Intelligence Agency (Kuby, 2019). Rousset's organisation was notably the cradle for the idea of "Communism's Nuremberg trial," including the staging of an actual mock trial of the USSR in 1951.

The anti-communism of the early period of European integration (Pruessen, 1996; Nguyen, 2016), with the FRG as the main target of inclusion, was vehemently attacked by the communist bloc. As a reaction to the anti-communist campaign in the West, beginning in the mid-1950s, the former Nazi concentration camps were turned into sites of anti-fascist commemoration across Communist countries (Lagrou, 1999). These sites were meant to demonstrate and pass on the lesson that millions of antifascist militants, under the alleged leadership of the Communists, suffered in Nazi camps that were actually on the other side of the front.

The Cold War played a key role in defining the discursive conditions for referencing the moral significance of the Second World War. By the end of the 1960s, two competing moral universalisms (Alexander, 2002, pp. 31-97; Jay, 2009, pp. 107-108) had developed on the continent. In the de-Stalinized socialist bloc, an official anti-fascism, re-appropriated and controlled by the Communist Party, coexisted with a pan-European leftist anti-fascist humanism in the sphere of culture and the arts (Agocs, 2017; 
Barker, 2013). In the anti-fascist framework of moral universalism, fascism served as a cultural emblem of radical evil, carrying with it the moral imperative of "Never again!" The universality of its historical significance derived from a humanistic stance: fascism was not a historical atrocity among others, but represented the ultimate assault on humanity. This explains why there was no distinct significance attributed to any of fascism's victim groups within this cultural framework. From a strict antifascist perspective, any hierarchy between the groups of Nazi victims was a reproduction of racial differentiation and was thus rejected. Accordingly, Jewish suffering was represented among the suffering of others, and Auschwitz was understood as a parallel to Hiroshima (Zwigenberg, 2014).

In the capitalist and anti-communist Western bloc, the universalist memory of the Holocaust acquired cultural and moral significance. In this cultural framework, it was the uniqueness of Jewish suffering that grounded moral universalization. The Cold War origins of this cultural framework are clearly visible in the Eichmann trial, which is considered as a constitutive historical event with regards to Holocaust consciousness in mainstream memory studies (Rothberg, 2007). In May 1960, Israeli Prime Minister David Ben-Gurion announced the capture of "one of the most prominent Nazi war criminals" in the midst of the Berlin crisis that eventually led to the building of the wall. By this time, East Germany was already attacking West German Chancellor Konrad Adenauer's integration and amnesty policies for former Nazis (Frei, 2002), calling attention to the "re-fascistification" of the Federal Republic (Lemke, 1993; Weinke, 2002; Miquel, 2004, pp. 23-81). From the Communist position, the crimes of Nazism, like the trial of Adolf Eichmann, were of contemporary importance. Eastern European countries, the GDR and those affected by Eichmann's past activities sought to influence the trial to include former accomplices, some of whom were still in high office in contemporary West Germany. In contrast, the FRG was interested in a trial reifying Nazi crimes as a matter of the past, and thus as a memory issue, and not as a German but as a Nazi problem. Ben-Gurion, who successfully expanded the scope of the trial so that it not only investigated Eichmann's actions but also became a dramatic portrayal of the Jewish genocide as a whole, repeatedly interceded on behalf of his West German ally (Yablonka, 2004). The scope of the trial developed in a complex field of forces, characterised by two divisions over the possible central focus: Eichmann's 
deeds (at which point the trial would have only considered the persecution of the Jews in Hungary - the only occupied territory where Eichmann was personally present during the deportations) versus the Holocaust as whole; and Eichmann alone versus Eichmann and those of his accomplices that had not yet been tried. Simply put, the West followed a moralising (de-criminalising) strategy while the East pursued a criminalising one. Each strategy was characterised by a temporality antagonistically opposed to the other. Eventually, the trial not only contributed to the emergence of the Holocaust as an event independent from the war and endowed with universal moral significance, but also - despite all efforts by the Eastern bloc - to the disintegration of the anti-fascist cult of wartime suffering. The moral legacy of Second World War became a memory issue about the Jewish genocide. An additional push in the development of the Holocaust-centred memory cult of the war was the issue of reparation payments, both by the West German state to Israel and by private West German firms to individual victims, which excluded the requests of Communists (Lagrou, 1999, pp. 279-280; Ferencz, 2002).

The second schism, which also led to the final collapse of anti-fascist moral universalism, was the anti-totalitarian moment in the 1970s when leftist intellectuals embraced an anti-totalitarian discourse to discredit Communist parties and communism as such (Christofferson, 2004). When critiquing totalitarianism, leftist intellectuals in the West turned away not only from communism, but from any kind of emancipatory movements that founded their cause on utopianism.

The very idea of the revolution is criminalised and automatically reduced to the category of 'communism' and thus archived in the 'totalitarianism' chapter in the history of the twentieth century. It is equated with Terror; a Terror reduced to the consistent achievement of a criminal ideology (Traverso, 2005, p. 88).

The idea of revolution and, in a broader sense, the idea that the necessary outcome of political action is the adjustment of social arrangements assuring a better life, became discredited and was replaced by the discourse of human rights. The anti-fascist struggle and the enormous sacrifice of Communists during the war was no longer a source of legitimacy 
for communism, even within leftist movements. The only reason why the anti-fascist legacy of the war was not completely buried in Europe until the developments of 1989-1991 was the fact that Communist regimes used and abused it as their official ideology.

A radical "retreat of politics into morality" in the 1970s proved to be decisive. This profound transformation of politics emerged as defensive reaction to the national liberation movements of decolonising territories. Far from being a rediscovery or boom (Moyn, 2010), the rise of human rights discourse in the 1970s was the neoliberal reinterpretation of human rights in the capitalist West in reaction to anti-colonial attempts to enforce the collective, economic and political interpretation of human rights in which the criminal responsibility of Western countries was underlined. From a global perspective, what happened in the 1970s appears not as an expansion of (human) rights, but as the disfranchisement and the renewed subordination of the Global South, striving for independence from colonial dominance (Slaughter, 2018). By the final decades of the Cold War, neoliberal human rights discourses had linked up with the developing construction of the cosmopolitan memory of the Holocaust, with the latter serving as the moral basis of the former. In this new political paradigm, there were no longer two ideologies in conflict, but individualised "pure" human suffering in opposition to any possibility of political or social transformation.

The other side of the Iron Curtain saw similar developments: Although neither the "memory boom" nor the official cultivation of Holocaust memory occurred in Eastern Europe, the meaning and practice of politics changed considerably among the dissidents, who after 1989 became key figures in the new political and intellectual elite. Following "the crumbling of socialist hopes after 1968" (Judt, 1988, p. 233) and the loss of faith in a socialism with a human face, dissidents engaged in the language of rights and the language of the totalitarianism framework in the name of "antipolitics" (Traverso, 2001), thereby bringing "human rights to its international public acme” (Moyn, 2010, p. 161).

In sum, since the 1970s, different historical developments have created the conditions of possibility for a new political discourse in the age of post-utopianism characterised by the retreat of politics into memory and 
morality; by a new historical consciousness and the usage of sacred Holocaust memory as a moral gauge; by individualism as political subjectification; by neoliberal human rights as an idea of justice; by antitotalitarianism as political program; and, importantly, by anti-communist, neoliberal ideology. In this new setting, anti-fascism disappeared from the political landscape, as did communism together with "its horizon of hope" (Traverso, 2005, p. 89). The question of communism would arise two decades later during the anti-communist moment in the form of a European memory issue, as the outcome of the post-Cold War reorganisation of the continental political space.

\section{THE WESTERN UNIVERSAL}

Although it played an important role in international public discourses, "until the 1990s, the memory of specific events of World War II was a black box that no political actor dared to open in the European arena" (Calligaro, 2015, p. 338; Probst, 2003). In the anti-communist moment, deprived of its ideological Cold War enemy, the EU gradually began to embrace the global Holocaust discourse. The European Parliament (EP) resolution in June 1995 still spoke the old language when it argued for the establishment of a Holocaust commemoration day by insisting that "the peace in Western Europe since 1945 will not continue if the totalitarian and racist ideologies of the Nazis which led to the Holocaust of the Jews, the genocide of the gypsies, the mass murder of millions of others and to the Second World War are not prevented from spreading their pernicious influence" (EP, 1995). By June 2000, the EP had already changed its discourse. According to the 'Declaration on the remembrance of the Holocaust' (EP 2000), the universal moral message of the memory of the Holocaust is a constitutive part of the European promotion of values. This declaration followed the Stockholm International Forum on the Holocaust in January 2000, an initiative by Swedish Prime Minister Göran Persson to strengthen Holocaust awareness. The so-called Stockholm Declaration (IHRA, 2000), signed by 46 country representatives, declares that "the unprecedented character of the Holocaust will always hold universal meaning," and "must be forever seared in our collective memory." As a moral touchstone "in our understanding of the human capacity for evil and good," the importance of the memory of the Holocaust reaches far beyond the realm of politics. Keeping alive the memory 
of the Holocaust is thus a moral obligation for the whole of humanity, because the latter is "still scarred by genocide, ethnic cleansing, racism, anti-Semitism and xenophobia." The signatories called on the international community "to fight those evils" and expressed their determination to strengthen the moral commitment of their peoples and governments "to ensure that future generations can understand the causes of the Holocaust and reflect upon its consequences." They also expressed their will to encourage "appropriate forms of Holocaust remembrance, including an annual Day of Holocaust Remembrance, in our countries." The EP's "Declaration" half a year later recapitulated these points from the Stockholm Declaration and called "on the Council and the Commission to encourage appropriate forms of Holocaust remembrance, including an annual European Day of Holocaust Remembrance" (EP, 2000). The moral commitment to the memory of the Holocaust was no longer framed within a particular political objective (peace), but instead found its conditions of legitimacy in universal relevance.

In reaction to the post-Cold War geopolitical reorganisation, the EU's integration policy began to localise the cosmopolitan memory of the Holocaust as a European historical experience with universal significance. The EU presidency statement on 31 October 2005 affirmed, "the significance of the Holocaust is universal. But it commands a place of special significance in European remembrance. It is in Europe that the Holocaust took place" (EU, 2005). The "special significance" of the Holocaust in European memory derives from the fact that the Holocaust as "the negative core event of the $20^{\text {th }}$ century" (Diner, 2003, p. 43) took place on the continent. After the "cult of heritage," the third wave of Europeanisation (Karlsson, 2010) is based on "a common European canon of remembrance [...] against the backdrop of the memory of the Holocaust as the constituting, in effect the inaugural event of a commonly shared European memory" (Diner, 2003, p. 42). It is now the historical lesson of the memory of the Holocaust that is supposed to provide solidarity and a sense of belonging to European citizens. The problem is not whether the memory of the Holocaust actually constitutes the "negative founding myth" of Europe, but that the attempt to interpret the commemoration of the Holocaust that way is real (Probst, 2003, p. 56). The European political project finds the condition of its legitimacy in references to this 
founding myth. All this spurs European institutions to foster the cultivation of cosmopolitan Holocaust memory both inside European borders and, through the enlargement process, in countries seeking entry.

As soon as Europe began to engage in the universalist Holocaust discourse and the politics of commemoration (Gensburger \& Lavabre, 2012), it faced the problem of managing the memory competition born of the "contagious exceptionalism" (Snyder, 2013, p. 88) produced by the uniqueness claim. In an attempt to resolve the escalating social conflicts around the claims of historical victimisation, European models of reconciliation (Jouhanneau \& Neumayer, 2014) were introduced, including a model based on the "politics of recognition" paradigm (Taylor, 1994; Honneth, 1992; Fraser \& Honneth, 2003), which argues for the integration of different memories into a common Holocaust memory framework, thereby fostering solidarity and commonly shared values by way of public recognition for the historical suffering of victims (Rigney, 2012).

By the late 1990s, the triumph of liberal democracy over the totalitarian regimes of the twentieth century had become the lesson of the Second World War. As Traverso ironically stated, "once the Janus-faced monster [was] beheaded, the West had a makeover, almost a new virginity. If Nazism and communism are the bitter enemies of the West, it ceases to be the cradle of them just to become their victim with liberalism assuming the role of its redeemer" (Traverso, 2005, pp. 90-91). The founding myth of Europe was rewritten and the core values of 'Europeanness' were promoted through the commemoration of the Jewish genocide as a European historical experience with universal relevance. The moral order articulated by the commemoration of the Holocaust has become the standard of civilisation imposed by Europe's international policy: both in the so-called integration process and in the vocation of maintaining humankind's universal rights in the world. From the European perspective, EU enlargement appeared as a process of integration through which continental civilisation was reunited according to its supposedly universal values. It followed that the norms of European historical consciousness were imposed as criteria of membership on candidate countries, as proof of democratic commitment, even of being civilised - that is, "European." 


\section{RETURN TO EUROPE}

The dissolution of the Eastern bloc was conceived as a "transition from dictatorship to democracy"; a teleological process leading to the full-scale establishment of a Western-type political and economic system. Since any alternative to political liberalism and free market capitalism was unimaginable on both sides of the enlargement process, the role of symbolical politics increased within the political arena. Post-Communist countries positioned themselves as already European nations "returning to Europe" that, by an accident of history, were previously stuck outside Western civilisation. Presenting oneself as European on the international stage was the main symbolic discursive strategy during EU (and also NATO) enlargement negotiations, stigmatising the other as non-European - that is, Eastern. The discourse of "returning to Europe," which united the two strategic reformulations of national identity and of European orientation (Zombory, 2012), played a crucial role in geopolitical repositioning until the late 1990s.

This Europe-discourse dates back to the 1980s, when dissident intellectuals in Eastern Europe strove to redraw the continent's binary civilisational map by positioning themselves as Central European. The intellectual movement around the concept of Central Europe was an influential yet short-lived attempt to take part in the definition of European values. As Milan Kundera (1983) emphatically argued, Central European nations had been "kidnapped" by the East yet culturally belonged to Western civilisation, despite communist political oppression. In 1956 and 1968, they showed their true affiliation to Europe by rising up against Soviet imperialism. In this cultural imagery, the fall of communist regimes finally moved back the civilisational border between East and West to where it had originally been located, so finally Central European nations again became part of the European political community of Western civilization. Though the idea of Central Europe lost political significance in the late 1990s, the narrative of reclaiming Europeanness remained influential.

In post-1989 state politics, the idea of return became the primary source of legitimacy in former Eastern European countries (Lagerspetz, 1999). The claim of returning to Europe differentiated the current from the previous "Eastern" regime and proved the democratic credentials necessary 
to join European institutions. For the new political elites that had been engaged in the Europe-discourse well before 1989, post-socialist politics also meant the return to a nation that was allegedly oppressed by communism - despite the fact that Communist regimes had strongly institutionalised national categories and sanctioned certain forms of nationalism (Brubaker, 1996). Since the "memory boom" in these countries coincided with a change in political regime, the social value attributed to memory increased markedly: it has become one of the main methods of producing historical truth. The discourse of return to historical truth through national memory construed the previous system as one based on lies. The change of regime was recounted as the historical victory of truth over a political and economic failure unsuccessfully whitewashed by the communist elite, and as the national recovery from decades-long oppression. In the post-Communist political imagination, the previous era was perceived as an unnatural interlude from which nations now returned to normalcy. State socialism was bracketed in the new national narratives as the dead end of history and a period in which the anti-European and anti-national East ruled.

The discourse of returning to Europe construed the political subject as a previously oppressed nation wishing to continue history from the point it swerved onto the "wrong" track with the Communist takeover. This is the reason why new elites tended to draw on the symbolic repertoire of the interwar period. The ultimate legitimising strategy of the new regimes was to distance themselves from the Communist past, thus producing a radical symbolic break with it in the re-enactment of what they considered to be the historically true - that is, national - past in every sector of society. As legislation on the restitution of nationalised property or the restorationist citizenship policies in Estonia and Latvia show (Budryte, 2011), the significance of the discourse on the return to Europe extended far beyond the realm of the symbolic. In the international context, the symbolical distancing of communism was supposed to serve as proof of European and thus Western qualities.

Accordingly, what was commemorated in the 1990s was not at all "communism," but the nation allegedly oppressed by communism. The founding myth of the new democracy rested on the idea that the revolutions of 1956 and 1968, now reframed as national uprising and political 
resistance against communism, would finally be completed; their demands once rejected, would now be realised (Mark, 2010). The new elites tended to frame negotiated transitions as legitimate culminations of earlier anti-communist struggles. The temporality of the "transition to democracy," no longer under Eastern oppression but not yet in Western liberty, was deeply future-oriented and attributed social meaning to the deeds of the nation in commemorative narratives, especially to the sacrifices it had made for freedom. Accordingly, it was mainly the classic technology of nation-building that inspired the memory politics of postCommunist countries in the 1990s. Cultural representations of the past relied heavily on the heroic historical role of the nation fighting for independence, defending Europe, or reflected allegedly ancient European attributes such as freedom and tolerance. During this period, there was no officially supported memory of communism. The denial of the communist experience went hand in hand with the reconstruction of the nation as non-communist. Anti-fascist ideology became completely and irrevocably delegitimised and discredited as a historical lie disseminated by the Communists in order to manipulate the nation and maintain their despotic domination.

In terms of spatial repositioning, commemorative narratives (in which the civilisational border moved while the people remained in place) localised present-day nations in the perceived transitional 'nowhere land' between East and West, no longer situated in the East but not yet in Europe. It was against this backdrop that countries aspiring to EU membership were called upon to meet the "soft" EU membership criterion of a Holocaust-centred historical consciousness (Leggewie, 2010; Judt, 2005, p. 803). Presenting oneself successfully as a European nation required a particular relationship to the past together with specific modes of memorial representation, with "coming to terms with the past" at the centre. During the accession process, post-socialist countries were interpellated as subjects that had to successfully overcome the burden of 40 years of totalitarian communism to be able to become European. As the moment of EU accession drew closer, and became more institutionalised, the European position on countries in the 'nowhere land' became more certain. PostCommunist states gradually obtained more resources and grounds for their claims in the transnational space of politics and were able to represent themselves as different in a way legitimised by the rules of the 
game. The state-supported memory of communism emerged as a result of this process (cf. Radonic, 2018; Subotic, 2019).

\section{THE EASTERN SPECIFIC}

In post-Communist countries, state efforts to "come to terms with" their totalitarian past were manifested in various forms of institutionalisation, providing space for and giving credence to political claims. These institutions were created to solve the fundamental dilemma: how to influence European politics in a legitimate way prior to gaining EU membership? In these newly created institutional spaces - historical commissions, institutes of national remembrance, and memorial museums -, the norms of historical consciousness prescribed during the enlargement process could interfere with often-conflicting national memory norms.

In 1998, the three Baltic presidents initiated the formation of national commissions of historians to study the "crimes against humanity" of the past totalitarian regimes (Pettai, 2015). Beyond implementing the international human rights language in the knowledge production about the past, the work of the commissions aimed to legitimise the construction of the memory of communism as a symbol of evil, while avoiding international criticism for relativizing or marginalising the memory of the Holocaust. Legitimate grounds to refuse these claims was provided by the membership of the commissions, which included acknowledged political figures and experts from the Western world, and by the fact that the commissions' work (also) dealt with the Holocaust. The strategy of juxtaposing suffering under Nazism and under communism, including the official terminology of "double genocide," was the outcome of this "reconciliation process" (Budryte, 2005, pp. 184-186).

Historical commissions played a significant role in Romania as well. The final report of the Presidential Commission for the Analysis of Communist Dictatorship, initiated by Romanian President Traian Băsescu in 2006 and chaired by Vladimir Tismăneanu, an acknowledged American political scientist of Romanian origins, provided the scholarly basis for the Romanian president to officially condemn communism as illegitimate and criminal. ${ }^{1}$ The president declared in the parliament: "Imported from the

1. See the article by Bogdan Iacob in this special issue. 
USSR, the Communist ideology justified the assault against civil society, against political and economic pluralism; it justified the annihilation of the democratic parties, the destruction of the free market, extermination by assassination, deportation, forced labor, and the imprisonment of hundreds of thousands of people." (Quoted in Apor, 2011, p. 573) The retrospective, even anachronistic application of concepts of civil society, political and economic pluralism, democratic parties or the free market to the social-political reality of 1940s Romania clearly showed that moral and ideological stakes were far more important in the president's statement than historical understanding (Mark, 2010, p. 38). As in the case of the Baltic historical commissions, the Romanian commission's work served as a discursive laboratory for Europeanising communism by representing it according to the model of canonical Holocaust memory and by implementing a legitimate discourse about the past. The Romanian case is a good demonstration of the rootedness of communism memory in the pan-European east-west cooperation of actors, since it was the historical commission that in 2006 recommended the creation of a museum of communist dictatorship that, "like the Holocaust Memorial in Washington, would be both a place of memory and an affirmation of the values of the open society" (quoted in Bădică, 2013, p. 113). Râmnicu Sărat, a former prison, was chosen as the site of the Memorial Museum for the Victims of Communism (see Bădică, 2013).

Beside historical commissions, memory institutes have been presented as another institutional form of national engagement with the past following the "German model." In fact, the region's model memorial institute, the polish Institute of National Remembrance (IPN), was actually embedded into the decades-long social history of Poland, and was at least as significant, if not more, as the German "Gauck Office" (the Bundesbehörde für Stasi-Unterlagen), established in late 1990 to regulate access to East German state security (Stasi) archives (Mink, 2017). One of the most important organisational features of IPN, established in 1998, was that alongside its archival and scholarly role, it had a judicial function to initiate criminal proceedings in connection with historical crimes. Yet, its historiographic role seems to be the most important (Behr, 2011), in particular since the impact of the IPN in this respect goes well beyond Poland, through institutional networking in the international, mainly post-Communist region, but also through its key role in the historiography of the 
anti-communist consensus. For instance, Andrei Paczkowski, a historian at the IPN, is one of the authors of the Black Book of Communism: Crime, Terror, Repression, published in France in 1997 and subsequently translated into 27 languages.

One of the regional resources of legitimacy was that the quasi statecontrolled institutions created in the context of EU enlargement channelled an already existing pan-European scholarly discourse of historical revisionism aimed at condemning communism in a legitimate way. In this regard, the Black Book is exemplary in terms of both its creation through an east-west cooperation and its impact on political claims on the memory of communism. ${ }^{2}$ The book was very influential in legitimising the condemnation of communism by juxtaposing it with Nazism, and identifying it (in the subtitle) with crime, terror and repression (Courtois, 1997). The Black Book provided the scholarly authority for condemning communism as a system as equally criminal as Nazism. Its novelty in relation to other anti-communist critiques of totalitarianism was that it performed the revision of history by a memory claim made in relation to the Holocaust. Its performative potential derives from reclaiming the memory of communism against the alleged erasure of its crimes. The strategy of reclaiming the memory of communism was legitimised by the modalities of Holocaust memory: by the imperative of "Never again!", by the call to restore the dignity of its victims, by the commemoration of past suffering as a means of stopping the repetition of the traumatic past. In post-Communist countries, the book was translated, discussed at conferences, and referred to in public debates. Courtois's arguments, especially his controversial comparison between the 100 million victims of communism and the 25 million victims of Nazism (Courtois, 1997, p. 25), were often presented, without the debate they triggered in France and internationally (Aronson, 2003), as rock-solid historical evidence of communism's criminal nature, sometimes even as well-known facts, without indications of sources (Schmidt, 2003[1999], p. 12). The book also influenced representations of communism in museums, as for example the exhibition "Two Faces of Totalitarianism: Twentieth Century Europe," organised in 2005 by the Polish Karta Center in Warsaw (Main, 2008, p. 389). Courtois personally and directly contributed in various ways to the political and institutional reclaiming of the memory of communism (Constantin, 2018):

2. See the article by Behr et al. in this special issue. 
as a participant of scholarly events organised in post-Communist countries; as a member of the Scientific Board of the International Center for Studies into Communism, affiliated to the Sighet Memorial Museum in Sighetu Marmaţiei; and as rector of an annual summer school organised by the museum's supporting foundation, which even published his lectures in Romanian (Courtois, 2003; Constantin, 2018).

The third typical institutional form in which pre-accession and extraEU east-west interaction took place was the memorial museum. Although these were often, at first at least, founded by anti-communist expatriates and domestic dissidents, by the late 1990s, governments in the region had begun to embrace their discourse (Zombory, 2017). When visualising and materialising the discourse of an anti-communist critique of totalitarianism, memorial museums perform the reclaiming of the "forgotten" memory of communism. Their exhibitions create a political space which is organised according to the equality of victimhood. At stake in this binary political space is the legitimate comparison of the two symbols of evil in history. Their source of legitimacy is derived from the de-politicised (that is, de-contextualised) representation of pure human suffering, from the victim's point of view. In memorial museums, even in those depicting only the repression under Communist regimes, communism appears as a similar counterpart to Nazism: "The depiction of Communism solely as a terror regime conspicuously next to the already established icon of violence, Nazism, is an attempt to transform the Gulag into a counter-Auschwitz, to construct an understanding of the history of Communism as the twin of the ultimate horrors of Nazism and as the Eastern double of the ultimate catastrophe of European civilisation" (Apor, 2012, p. 574). The construction of this relation is based on the ideology of anti-totalitarianism, which presents both systems as inherently characterised by terror and crime, and thus by the violation of the human rights of innocent individuals. In the political space of comparison, which is in fact the space of competition, the diverse historical experiences of state socialism are transformed into a uniform historical trauma, as equally unimaginable as the Holocaust, which is also detached from the historical complexity of the Second World War - what can be debated, then, is the degree of human suffering in the two cases. It is against this backdrop that one of the most important arguments for challenging the uniqueness claim of the Holocaust was formulated: the West applies double standards when 
recognising and restoring the dignity of the victims of Nazism, while denying the same to the victims of communism.

The re-appropriation of the norms of legitimate historical consciousness by post-Communist countries entailed the modification of anti-communist revisionism. While the Black Book deals with communism as a world phenomenon, in the post-Communist context, the memory of communism came into existence not only as European, but also as Eastern. Its specificity in relation to universalist Holocaust memory is not historical but geographical. Memorial museums played a crucial role in localising the memory of communism as Eastern, particularly those which were established on sites of political violence: the House of Terror Museum in Budapest, the Sighet Memorial, Râmnicu Sărat, or the Museum of Genocide Victims in Vilnius (1992) (renamed as Museum of Occupations and Freedom Fights). The Museum of Occupations in Riga occupies the building that until 1991 housed the museum for the Latvian Riflemen, a group that supported the Bolsheviks during the Russian revolution and the ensuing civil war. Considerable efforts have been made to erase the ideologically undesirable reminiscence of the building's history (Mark, 2008, pp. 362-363), and the museum had even planned a move to the former building of the NKVD (Denis, 2011). Though located in a new purpose-built building, the Museum of Occupations in Tallinn, redesigned in 2018 (Pääbo \& Pettai, 2019), also aims, according to the objectives of the host institution, to be "a tombstone for the thousands of countrymen buried in anonymous graves” (Kistler-Ritso Estonian Foundation, 1998).

These institutions' main strategy in historical representation is to rely on the "spirit of the place": the genius loci, embedded in the material building or site, is not subjected to historical change. The sites of exhibition are thus supposed to be the "objective witnesses" of history, establishing the identity of past and present (the site left as it was at the time of political violence). It follows that the memorial site acquires the meanings of a crime scene where, according to the European vocabulary, human rights were severely violated. In domestic politics, the location of memorial museums made it possible to discredit the post-communist left, while on the international scene, it made communism site specific. Reclaiming the memory of a Europeanised communism produced a legitimate historical experience that differentiated the newcomers from the "old member 
states." The idea of "double victimhood" has become the differentia specifica of post-Communist countries, which position themselves as an Eastern Europe that is, specifically European, which lived through both totalitarian regimes in the twentieth century. This has served as a symbolic resource in the ongoing transnational competition over culturally identical "historical experiences." The memory of communism has been localised as specifically East European, as a counterpart to European Holocaust memory, perceived as Western.

In a sense, European norms of historical consciousness have been nationalised. In the European discourse on Holocaust memory, which positioned local authorities and populations as collaborators, and thus continuously undermined national pride and self-esteem especially in the eyes of the political right, the memory of communism could be presented as the other dark side of history. National pride is paradoxically to be regained by the degree of suffering under communism, allegedly more severe than under Nazism. Reducing the memory of the state socialist period to terror and violence is, beyond demonstrating the brutality and inhuman nature of Communist rule, supposed to represent the regime as an alien force that society, conceived of as the nation, had nothing to do with except for being the innocent victim and enduring foreign domination (Kopeček, 2008). It follows that communism is represented in sharp contrast to the nation: communism is isolated from the nation and essentially anti-national; thus, the nation is anti-communist and an innocent victim untainted by totalitarian, terrorist and criminal communism. The true subject of history is the nation, whose ahistorical, eternal and homogeneous essence is represented in relation to the meanings attributed to communism.

Less than a decade after the collapse of Communist regimes, the region thus witnessed a considerable change in national discourse. The symbolical distancing of the Communist past took another form: from the dead end of history, an unmarked signifier, communism has been transformed into the symbol of the evil of history and the ultimate perpetrator, commemorated and condemned alongside Nazism. The nation, characterised as the heroic protagonist in the narrative of historical struggles of the mythic forces of West and East, is now constructed as an East European community of victims, repressed by both totalitarian regimes, but mainly 
by communism. All this implied the transformation of post-Communist anti-communism: it has been re-formed according to the European norms expressed in the representational canon of cosmopolitan Holocaust memory.

\section{CONCLUSION}

By the time post-Communist countries gained EU membership and the ability to influence European politics from the inside, the chance to subvert the normative regime of historical consciousness was already gone. Since new member states had already appropriated the norms of legitimate difference before legal accession, the debate about the meanings of Europe was reduced to the mimetic competition of self-victimised actors whose memories are similar enough not to curtail the other's claims for recognition. In fact, they only differ in terms of their geographical localisation. The intense competition between these two culturally very similar representations is what Freud termed narcissism of small differences: because of their similitude, the stakes of being different are increasingly high (Freud, 2002[1929]).

Relying on Bourdieu's field theory, this paper has argued that pre-accession social space, in which players strove to influence the definition of the political community ("Europeanness"), was characterised by extreme objective inequality. That is, integrators could impose the symbolic criteria of accession to those to be integrated, which in this case was the normative historical consciousness based on cosmopolitan Holocaust memory. As a result, new players could enter the field only by demonstratively adopting this normative system and could only strive to acquire their differentia specifica in its inherent logic. They were to delegitimise the prevailing principle of differentiation (the uniqueness claim) by relying on the very same rules of the play in opposition to the "rulers" attempt to delegitimise any such attempt of delegitimisation. The whole resulting mimetic victimhood rivalry unfolded around the principles of legitimacy (in this case: historical authenticity) and thus detached itself from historical reality. This reminds us of the cultural logic of the field of restricted production, described by Bourdieu, which "tends to obey its own logic, that of the continual outbidding inherent to the dialectic of cultural distinction." "Thus, the more cultural producers form a closed 
field of competition for cultural legitimacy, the more the internal demarcations appear irreducible to any external factors of economic, political or social differentiation" (Bourdieu, 1985a, pp. 17-18). This is exactly what happened in the case of conflicting self-proclaimed spokespersons of victimised groups, when each claimed to stand for one "historical experience" defined exclusively with regards to the opposing other. They formed a close field of competition for political legitimacy.

As argued in this paper, the anti-communist moment is heavily responsible for this socio-cultural dynamic. The gradual de-legitimisation of antifascism after the Second World War - first as a political movement, then as a cultural framework of moral universalism - culminated in the 1970s, followed by a genuine anti-communist moment when self-proclaimed anti-fascist Communist states collapsed in 1989-1991. Against the background of the European anti-communist consensus, between liberal and conservative, and capitalist and post-Communist, competitive victimhood unfolded as a political struggle for legitimate difference. In the context of EU enlargement, the essentially anti-communist construction of Cold War cosmopolitan Holocaust memory became a prerequisite for democratisation. As a result of social interactions during the accession process, postCommunist memory was transformed into a civilised anti-communist memory constructed according to the European norms of historical consciousness expressed by the canon of cosmopolitan Holocaust memory. At the same time, political representation became possible for those aiming at entering the field of the debate by assuming the victim position. It was thus not political interests, determined by different historical experiences, that were represented in the discussion of Europe's political boundaries, but the authenticity of historical experience. The $2009 \mathrm{EP}$ resolution on European Conscience and Totalitarianism is a symptomatic example of how the commonly shared moral supremacy of anti-communism prevented any discussion of communism as a historical reality. The resolution, which condemns Communism as inherently totalitarian, testifies to the anti-communist consensus: it was voted by an extreme majority $(70,57 \%)$ of total EP seats and was objected by less than $6 \%$, with $80.5 \%$ of participation in the vote (Neumayer, 2019, p. 124). What is more important, when the initiative to criminalise communism was criticised at all, it was not because of opposition to its anti-communism but for fear of relativizing the memory of the Holocaust. 
The anti-communist moment provided no space for ideological or political difference. New member states could acquire a legitimate subject position - meaning, Europeanness - only by proving their democratic qualities, expressed by the cultivation of a universalist Holocaust memory. They positioned themselves as specifically Eastern by also reclaiming the memory of communism in a European way. As a symbolic resource in political struggles, the "historical experience of communism" served as a legitimate difference in relation to the universality of European Holocaust memory. Far from being the consequence of different historical legacies, the east-west divide in the European memory landscape is the result of the struggle for the legitimate principles of difference.

\section{BIBLIOGRAPHY}

AGOCS Andreas (2017), Anti-Fascist Humanism and the Politics of Cultural Renewal in Germany, Cambridge/New York: Cambridge University Press.

ALEXANDER Jeffrey C. (2002), “On the Social Construction of Moral Universals: The 'Holocaust' from War Crime to Trauma Drama," European Journal of Social Theory, vol. 5, no. 1, pp. 5-85.

APOR Péter (2011), "Master Narratives of Contemporary History in Eastern European National Museums," in Great Narratives of the Past. Traditions and Revisions in National Museums Conference Proceedings from EuNaMus, European National Museums: Identity Politics, the Uses of the Past and the European Citizen, Paris 29 June - 1 July o 25-26 November 2011, p. 569-585, Linköping Electronic Conference Proceedings, Linköping University Electronic Press, http:// www.ep.liu.se $/$ ecp/contents.asp?issue $=078 \&$ volume $=$ [Accessed 10 July 2020].

ARONSON Ronald (2003), "Communism's Posthumous Trial," History and Theory, vol. 42, no. 2, pp. 222-245.

ASSMANN Aleida (2011), "Europe’s Divided Memory,” in M. Blaive, C. Gerbel \& T. Lindenberger (eds), Clashes in European Memory: The Case of Communist Repression and the Holocaust, Innsbruck, Vienna, Bozen: StudienVerlag, pp. 270-280.

BĂDICĂ Simina (2013), “Curating Communism: A Comparative History of Museological Practices in Post-War (1946-1958) and Post-Communist Romania," doctoral dissertation in history, Budapest: Central European University.

BARKER Jennifer Lynde (2013), The Aesthetics of Anti-Fascism Film: Radical Projection, New York: Routledge.

BEHR Valentin (2011), "Historiens militants ou historiens de bureau? Les producteurs du récit historique officiel à l'Institut de la Mémoire nationale," Revue d'études comparatives Est-Ouest, vol. 42 , no. 4 , pp. 5-35. 
BOURDIEU Pierre (1980), Le sens pratique, Paris: les Éditions de Minuit.

BOURDIEU Pierre (1982), Ce que parler veut dire: L'économie des échanges linguistiques, Paris: Fayard.

BOURDIEU Pierre (1985a), "The market of symbolic goods," Poetics, vol. 14, no. 1-2, pp. 13-44.

BOURDIEU Pierre (1985b), "The Social Space and the Genesis of Groups," Theory and Society, vol. 14 , no. 6 , pp. $723-744$.

BRUBAKER Rogers (1996), Nationalism Reframed: Nationhood and the National Question in the New Europe, Cambridge / New York: Cambridge University Press.

BUDRYTE Dovile (2005), Taming Nationalism? Political Community Building in the Post-Soviet Baltic States (Post-Soviet Politics), Hampshire: Ashgate.

BUDRYTE Dovile (2011), "From Ethnic Fear to Pragmatic Inclusiveness? Political Community Building in the Baltic States (1988-2004)," Ethnicity Studies/Etniškumo Studijos, vol. 1, no. 2, pp. 14-41.

BULL Anna Cento \& HANSEN Hans Lauge (2016), "On Agonistic Memory," Memory Studies, vol. 9 , no. 4 , pp. $390-404$.

CALLIGARO Oriane (2015), "Legitimation Through Remembrance? The Changing Regimes of Historicity of European Integration," Journal of Contemporary European Studies, vol. 23, no. 3, pp. 330-343.

CHAUMONT Jean-Michel (1997), La concurrence des victimes: Génocide, identité, reconnaissance, Paris: Éditions La Découverte.

CHRISTOFFERSON Michael Scott (2004), French Intellectuals Against the Left: The Antitotalitarian Moment of the 1970's, New York: Berghahn Books.

CONSTANTIN Anemona (2018), "Le Mémorial de Sighet, entre 'devoir de mémoire' et contraintes de l'histoire," Studia Politica: Romanian Political Science Review, vol. 18, no. 3, pp. 507-543.

COURTOIS Stéphane (1997), "Les crimes du communisme," in S. Courtois et al., Le livre noir du communisme : Crimes, terreur et répression, Paris: Robert Laffont, pp. 9-41.

COURTOIS Stéphane (2003), Courtois la Sighet [Courtois at Sighet], edited by I. Boca, Bucharest: Fundația Academica Civică.

CSIGÓ Péter (2016), The Neopopular Bubble: Speculating on "the People" in Late Modern Democracy, Budapest/New York: Central European University Press.

DENIS Juliette (2011), "Entretiens avec les directeurs du Musée juif et du Musée de l'occupation de Riga, les 29 et 30 avril 2011, à Riga, Lettonie," The Journal of Power Institutions in Post-Soviet Societies, no. 12, https://journals.openedition.org/pipss/3890 [Accessed 10 July 2020].

DINER Dan (2003), "Restitution and Memory: The Holocaust in European Political Cultures," New German Critique, no. 90, pp. 36-44. 
DROIT Emmanuel (2007), "Le Goulag contre la Shoah," Vingtième siècle: Revue d'histoire, vol. 94 , no. 2 , pp. 101-120.

European Parliament (1995), "Resolution on a day to commemorate the Holocaust," Official Journal of the European Communities C 166, 03/07/1995 P. 0132, https://op.europa.eu/en/ publication-detail/-/publication/7622aa58-21bc-445c-b820-760d6303555a/language-en [Accessed 10 July 2020].

European Parliament (2000), "Declaration on the remembrance of the Holocaust," https:// www.europarl.europa.eu/sides/getDoc.do?pubRef=-//EP//NONSGML+WDECL+P5-DCL2000-0003+0+DOC $+\mathrm{PDF}+\mathrm{V} 0 / / \mathrm{EN} \&$ language $=\mathrm{EN}$ [Accessed 10 July 2020].

European Union (2005), "EU Presidency Statement - Holocaust Remembrance” (31 October 2005: New York), http://eu-un.europa.eu/articles/en/article_5224_en.htm [Accessed 10 July 2020].

FERENCZ Benjamin B. (2002), Less than Slaves: Jewish Forced Labor and the Quest for Compensation, Bloomington: Indiana University Press in association with the United States Holocaust Museum.

FRASER Nancy \& HONNETH Axel (2003), Redistribution or Recognition? A Political-Philosophical Exchange, London/New York: Verso.

FREI Norbert (2002), Adenauer's Germany and the Nazi Past: The Politics of Amnesty and Integration, New York: Columbia University Press.

FREUD Sigmund (2002[1929]), Civilization and its Discontents, London: Penguin.

GENSBURGER Sarah \& LAVABRE Marie-Claire (eds) (2012), "D’une 'mémoire européenne' à l'européanisation de la 'mémoire,” special issue of Politique européenne, no 37, pp 9-17.

GUPTA Akhil \& FERGUSON James (1992), "Beyond 'Culture': Space, Identity, and the Politics of Difference,” Cultural Anthropology, vol. 7, no. 1, pp. 6-23.

GUPTA Akhil \& FERGUSON James (eds) (2001), Culture, Power, Place: Explorations in Critical Anthropology, Durham, NC: Duke University Press.

HALBWACHS Maurice (1925), Les cadres sociaux de la mémoire, Paris: F. Alcan.

HONNETH Axel (1992), Kampf um Anerkennung: Zur moralischen Grammatik sozialer Konflikte [The struggle for recognition: On the moral grammar of social conflicts], Frankfurt: Suhrkamp.

International Holocaust Remembrance Alliance (IHRA) 2000, Stockholm Declaration, https:// www.holocaustremembrance.com/about-us/stockholm-declaration [Accessed 10 July 2020].

JAY Martin (2009), “Allegories of Evil: A Response to Jeffrey Alexander,” in J. Alexander et al. (eds), Remembering the Holocaust: A Debate, Oxford: Oxford University Press, pp. 105113.

JOUHANNEAU Cécile \& NEUMAYER Laure (2014), “Introduction,” Revue d'études comparatives Est-Ouest, vol. 45, no. 3-4, pp. 5-19.

JUDT Tony (1988), “The Dilemmas of Dissidence: The Politics of Opposition in East-Central Europe,” East European Politics \& Societies, vol. 2, no. 2, pp. 185-240. 
JUDT Tony (2005), Postwar: A history of Europe since 1945, London: Penguin Press.

KARLSSON Klas-Göran (2010), "The Uses of History and the Third Wave of Europeanisation," in M. Blaive, C. Gerbel \& T. Lindenberger (eds), A European Memory? Contested Histories and Politics of Remembrance, New York: Berghahn Books, pp. 38-55.

KATTAGO Siobhan (2009), "Agreeing to Disagree on the Legacies of Recent History: Memory, Pluralism and Europe after 1989," European Journal of Social Theory, vol. 12, no. 3, pp. 375-395.

Kistler-Ritso Estonian Foundation (1998), "Goals and Objectives," http://www.okupatsioon.ee/ index.php/et/home/whoweare [Accessed 26 October 2016].

KOPEČEK Michal (ed.) (2008), History in the making: Historical Revisionism in Central Europe since 1989, Budapest, New York: Central European University Press.

KUBY Emma (2019), Political Survivors: The Resistance, the Cold War, and the Fight against Concentration Camps after 1945, Ithaca: Cornell University Press.

KUNDERA Milan (1983), “Un Occident kidnappé,” Le Débat, no. 27, pp. 3-23.

LAGERSPETZ Mikko (1999), "Postsocialism as a Return: Notes on a Discursive Strategy," East European Politics \& Societies, vol. 13, no. 2, pp. 377-390.

LAGROU Pieter (1999), The Legacy of Nazi Occupation: Patriotic Memory and National Recovery in Western Europe, 1945-1965, Cambridge/New York: Cambridge University Press.

LEGGEWIE Claus (2010), "Equally Criminal? Totalitarian Experience and European Memory," Tr@nsit Online, http://www.iwm.at/read-listen-watch/transit-online/equally-criminal/ [Accessed 10 July 2020].

LEMKE Michael (1993), "Kampagnen gegen Bonn: Die Systemkrise der DDR und die WestPropaganda der SED 1960-1963" [Campaigns against Bonn: The systemic crisis of the GDR and the SED's West-Propaganda 1960-1963], Vierteljahrshefte für Zeitgeschichte, vol. 41, no. 2, pp. 153-174.

LEVY Daniel \& SZNAIDER Natan (2002), "Memory Unbound: The Holocaust and the Formation of Cosmopolitan Memory," European Journal of Social Theory, vol. 5, no. 1, pp. 87-106.

MAIER Charles S. (1993), "A Surfeit of Memory? Reflections on History, Melancholy and Denial," History and Memory, vol. 5, no. 2, pp. 136-152.

MAIN Izabella (2008), "How Is Communism Displayed? Exhibitions and Museums of Communism in Poland," in O. Sarkisova \& P. Apor (eds), Past for the Eyes: East European Representations of Communism in Cinema and Museums after 1989, Budapest, New York: Central European University Press, pp. 371-400.

MÄLKSOO Maria (2014), "Criminalizing Communism: Transnational Mnemopolitics in Europe,” International Political Sociology, vol. 8, no. 1, pp. 82-99.

MARK James (2008), "Containing Fascism: History in Post-Communist Baltic Occupation and Genocide Museums," in O. Sarkisova \& P. Apor (eds), Past for the Eyes: East European Representations of Communism in Cinema and Museums after 1989, Budapest, New York: Central European University Press, pp. 335-369. 
MARK James (2010), The Unfinished Revolution: Making Sense of the Communist Past in CentralEastern Europe, New Haven: Yale University Press.

MINK Georges (2011), "Geopolitics, Reconciliation and Memory Games: For a New Social Memory Explanatory Paradigm,” in M. Blaive, C. Gerbel \& T. Lindenberger (eds), Clashes in European Memory: The Case of Communist Repression and the Holocaust, Innsbruck, Vienna, Bozen: StudienVerlag, pp. 255-269.

MINK Georges (2017), “Is There a New Institutional Response to the Crimes of Communism? National Memory Agencies in Post-Communist Countries: The Polish Case (1998-2014), with References to East Germany,” Nationalities Papers, vol. 45, no. 6, pp. 1013-1027.

MINK Georges \& NEUMAYER Laure (2013), History, Memory and Politics in Central and Eastern Europe: Memory Games, Houndsmill, Basingstoke: Palgrave Macmillan.

MINK Georges, NEUMAYER Laure \& BONNARD Pascal (2007), L'Europe et ses passés douloureux, Paris: La Découverte.

MIQUEL Marc von (2004), “Ahnden oder amnestieren? Westdeutsche Justiz und Vergangenheitspolitik in den sechziger Jahren" [Punishment or amnesty? West German justice and the politics of the past in the 1960s], Beiträge zur Geschichte des 20. Jahrhunderts, vol. 1, Göttingen: Wallstein.

MOYN Samuel (2010), The Last Utopia: Human Rights in History, Cambridge, New York: Cambridge University Press.

NEUMAYER Laure (2015), "Integrating the Central European Past into a Common Narrative: The Mobilizations Around the 'Crimes of Communism' in the European Parliament," Journal of Contemporary European Studies, vol. 23, no. 3, pp. 344-363.

NEUMAYER Laure (2019), The Criminalisation of Communism in the European Political Space after the Cold War, London: Routledge.

NGUYEN Thi Thuy Hang (2016), “US and European Integration Prior to 1968," Lithuanian Foreign Policy Review, vol. 33, no. 1, pp. 83-109.

NOVICK Peter (1999), The Holocaust in American Life, Boston, New York: Houghton Mifflin Company.

PÄÄBO Heiko \& PETTAI Eva-Clarita (2019) “A Museum of Memories: The New 'Vabamu' in Tallinn," Cultures of History Forum, https://www.cultures-of-history.uni-jena.de/exhibitions/ estonia/a-museum-of-memories-the-new-vabamu-in-tallinn/ [Accessed 10 July 2020].

PAKIER Małgorzata \& STRÅTH Bo (eds) (2010), A European Memory? Contested Histories and Politics of Remembrance, New York: Berghahn Books.

PETTAI Eva-Clarita (2015), "Negotiating History for Reconciliation: A Comparative Evaluation of Baltic Presidential Commissions,” Europe-Asia Studies, vol. 67, no. 7, pp. 1079-1101.

PROBST Lothar (2003), "Founding Myths in Europe and the Role of the Holocaust," New German Critique, no. 90, pp. 45-58.

PRUESSEN Ronald W. (1996), “Cold War Threats and America's Commitment to the European Defense Community: One Corner of a Triangle," Journal of European Integration History, vol. 2, no. 1, pp. 51-70. 
RADONIC Ljiljana (ed.) (2018), “The Holocaust/Genocide Template in Eastern Europe,” special issue of Journal of Genocide Research, vol. 20, no. 4, pp. 483-489.

RIGNEY Ann (2012), "Reconciliation and Remembering: (How) Does It Work?," Memory Studies, vol. 5, no. 3, pp. 251-258.

ROTHBERG Michael (2007), "Beyond Eichmann: Rethinking the Emergence of Holocaust Memory," History and Theory, vol. 46, no. 1, pp. 74-81.

ROTHBERG Michael (2009), Multidirectional Memory: Remembering the Holocaust in the Age of Decolonization, Stanford: Stanford University Press.

ROUSSO Henry (2011), “The History of Memory: Brief Reflections on an Overloaded Field,” in M. Blaive, C. Gerbel \& T. Lindenberger (eds), Clashes in European Memory: The Case of Communist Repression and the Holocaust, Innsbruck, Wien, Bozen: StudienVerlag, pp. 231-238.

SCHMIDT Mária (2003[1999]), “'Holocaustok’ a huszadik században” [Holocausts in the twentieth century], in Egyazon mércével. A visszaperelt történelem [With the same standard: History sued back], Budapest: Magyar Egyetemi K, pp. 10-16.

SEIDMAN Michael (2018), Transatlantic Anti-Fascisms from the Spanish Civil War to the End of World War II, Cambridge, New York: Cambridge University Press.

SIERP Aline \& WÜSTENBERG Jenny (2015), "Linking the Local and the Transnational: Rethinking Memory Politics in Europe," Journal of Contemporary European Studies, vol. 23, no. 3, pp. 321-329.

SLAUGHTER Joseph R. (2018), "Hijacking Human Rights: Neoliberalism, the New Historiography and the End of the Third World," Human Rights Quarterly, vol. 40, no. 4, pp. 735-775.

SNYDER Timothy (2013), “Commemorative Causality,” Modernism/modernity, vol. 20, no. 1, pp. 77-93.

SUBOTIC Jelena (2019), Yellow Star, Red Star: Holocaust Remembrance after Communism, Ithaca: Cornell University Press.

TAYLOR Charles (1994), “The Politics of Recognition,” in A. Gutmann (ed.), Multiculturalism and the Politics of Recognition, Princeton: Princeton University Press, pp. 25-73.

TODOROV Tzvetan (1995), Les abus de la mémoire, Paris: Arléa.

TODOROV Tzvetan, (2000), Mémoire du mal, tentation du bien: Enquête sur le siècle, Paris: Robert Laffont.

TÓTH Manó (2019), “Challenging the Notion of the East-West Memory Divide," Journal of Common Market Studies, vol. 57, no. 5, pp. 1031-1050.

TRAVERSO Enzo (2001), Le totalitarisme: Le XXe siècle en débat, Paris: Seuil.

TRAVERSO Enzo (2005), Le passé, modes d'emploi: Histoire, mémoire, politique, Paris: La Fabrique Editions.

YABLONKA Hanna (2004), The State of Israel vs. Adolf Eichmann, New York: Schocken Books. 
WEINKE Annette (2002), Die Verfolgung von NS-Tätern im geteilten Deutschland: Vergangenheitsbewältigungen 1949-1969, oder, eine deutsch-deutsche Beziehungsgeschichte im Kalten Krieg [The persecution of Nazi perpetrators in divided Germany: Dealing with the past 1949-1969, or, A history of German-German relationships in the Cold War], Paderborn: F. Schöningh.

ZOMBORY Máté (2012), Maps of Remembrance: Space, Belonging and Politics of Memory in Eastern Europe, Budapest: L'Harmattan.

ZOMBORY Máté (2017), “The Birth of the Memory of Communism: Memorial Museums in Europe," Nationalities Papers, vol. 45, no. 6, pp. 1028-1046.

ZWIGENBERG Ran (2014), Hiroshima: The Origins of Global Memory Culture, Cambridge, New York: Cambridge University Press. 